\title{
Doctor who supported tax reforms removed from board of Doctors Nova Scotia
}

\author{
n Cite as: CMAJ 2017 December 11;189:E1539-40. doi: 10.1503/cmaj.109-5535
}

Posted on cmajnews.com on Nov. 23, 2017.

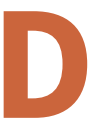

r. Monika Dutt, a Nova Scotia family physician who supported the controversial tax reforms proposed by the federal government, has been removed from the board of directors of Doctors Nova Scotia. Dutt was one of the signatories of an open letter to Finance Minister Bill Morneau that supported removing certain tax benefits of incorporation as a step toward a fairer tax system. Most physicians, however, have been adamant in their opposition to the proposed changes.

"I am not able to speak to the reason why I was removed from the Board of Doctors Nova Scotia," said Dutt. "I can, however, speak to why I and many others supported the federal tax proposal, which was in contrast to the stance taken by national and provincial associations."

Poor health outcomes are related to income inequality, and one way to address those health disparities is through taxation, said Dutt. Physicians are among the top $1 \%-5 \%$ of income earners in Canada, and the tax benefits available to some doctors are not available to the vast majority of Canadians, or even to all physicians. Doctors who called for a more equitable tax system, however, were often met with "overt hostility" from peers on social media and in medical leadership, said Dutt.

"Many did not speak publicly of their support for the tax changes as they were worried about negative repercussion from colleagues," said Dutt. "Unfortunately, taxation discourse amongst physicians has often been marked by a dismissal or stifling of differing opinions and unprofessional behaviour by some."

Doctors Nova Scotia did not say that Dutt's public support of the proposed tax

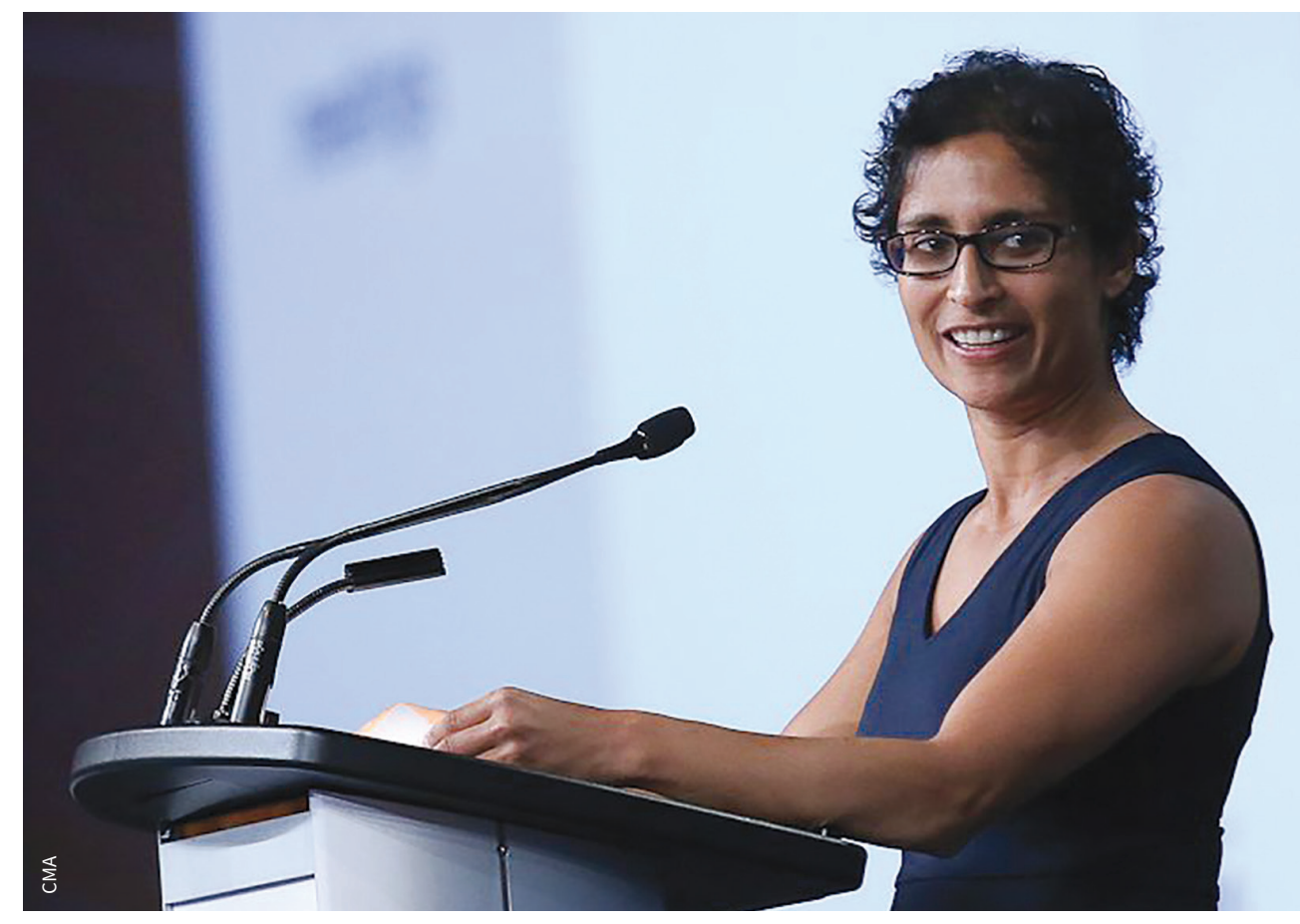

Dr. Monika Dutt has experienced hostility from some other doctors for her public support of controversial tax reforms.

changes led to her removal from the board. In a statement, Dr. André Bernard, the board's chair, said the board has a governance framework, which includes a policy that "clearly outlines the expectations with regard to conflict of interest and confidentiality." Board members are also "educated on their role and responsibilities."

"That framework prevents us from commenting further on the specifics; however, the board is confident that the proper process was followed in addressing this matter," the statement concluded.

Dutt is a well-known physician and public health advocate. She is a past chair of Canadian Doctors for Medicare and a former medical officer of health in Nova
Scotia, Saskatchewan and Ontario. She is the executive director of Upstream, a nonprofit with a goal to "create a healthy society through evidence-based, peoplecentred ideas." She is also on the board of directors of the Broadbent Institute, an independent organization that champions new approaches to government and

There was no shortage of opinion on Twitter when news broke about Dutt's dismissal. Dr. Jillian Ratti, a family physician in Alberta, suggested that Doctors Nova Scotia "unfortunately doesn't believe it can or should represent diverse opinions simultaneously." Dr. Ron George, an anesthesiology professor at Dalhousie University, said the board had leadership. 
lost an important voice and that he hoped Doctors Nova Scotia was going to offer its members more explanation about the decision. According to Dr. Jill Konkin, an associate professor of family medicine at the University of Alberta, the vote to remove Dutt was a "sad commentary" on Doctors Nova Scotia because medical associations need "a broad range of views to come to creative, innovative solutions."

Not everyone agreed, however, that the dismissal was unjustified. According to Chris Struthers from British Columbia, who describes himself as a "hardworking business owner," the decision to remove
Dutt was not surprising or problematic. "If councillors on my engineering association openly pushed for raising my taxes, l'd be voting them off ASAP," he wrote. "You can't well represent members if you hold very unpopular opinions."

Roger Collier, CMAJ 